\title{
KAJIAN YURIDIS PENETAPAN SANKSI DI BAWAH SANKSI MINIMUM DALAM PENYALAHGUNAAN NARKOTIKA
}

\author{
M. Nurdin \\ Dosen Fakultas Hukum Universitas Samudra, Meurandeh-Langsa \\ nurdin_yunus@yahoo.com
}

\begin{abstract}
The crime of narcotics is a form of extraordinary crime. Regulating narcotics criminal law as regulated in Law Number 35 of 2009 concerning Narcotics, in which a minimum threat is formed. This also applies to Article 114 paragraph (1) of Law No. 35 of 2009 concerning Narcotics. Matters did by judges who use the minimum decision. The problems studied are how the regulation of narcotics criminal sanctions is associated with sanctions under minimum sanctions. And, what are the legal consequences of the decision of the judge who decides the criminal case of narcotics with a sanction below the minimum. The method used is normative juridical method, namely the library research method by tracing secondary data.
\end{abstract}

Keywords: judge authority, minimum sanctions, narcotics

Abstrak, Tindak pidana narkotika merupakan salah satu pidana khusus dalam bentuk extra ordinary crime. Pengaturan hukum tindak pidana narkotika diatur dalam Undang-Undang No. 35 Tahun 2009 tentang Narkotika, dimana di dalamnya mengatur tentang ancaman pidana minimum. Hal ini dapat dilihat dalam Pasal 114 ayat (1) Undang-Undang No. 35 Tahun 2009 tentang Narkotika. Dalam Pasal tersebut terdapat pertentangan apa yang seharusnya dipertimbangkan oleh hakim dalam mengambil keputusan dalam hal penerapan pidana dengan ancaman pidana minimum tersebut. Adapun permasalahan yang dikaji yaitu bagaimanakah pengaturan sanksi tindak pidana narkotika dikaitkan dengan sanksi di bawah sanksi minimum. Dan, bagaimanakah konsekuensi hukum terhadap putusan hakim yang memutuskan perkara pidana narkotika dengan sanksi di bawah minimum. Metode yang digunakan adalah metode yuridis normatif yaitu metode penelitian kepustakaan dengan mengelusuri data sekunder.

Kata kunci: kewenangan hakim, sanksi minimum, narkotika

\section{Pendahuluan}

Penyalahgunaan narkotika dinilai sangat meresahkan dan memberikan dampak negatif yang ditimbulkan dari penggunaan narkotika ini. Pemerintah telah menetapkan peringatan bahwa Indonesia merupakan negara darurat narkotika. Dengan adanya peringatan darurat narkotika, para pengguna, pembeli dan pengedar narkotika semestinya 
mendapatkan sanksi yang berat. Salah satu sanksi yang diberikan kepada penyalahguna narkotika berupa sanksi pidana penjara. ${ }^{1}$

Merujuk pada tataran sanksi pidana yang diatur dalam pidana nasional, khususnya dalam Kitab Undang-undang Hukum Pidana (KUHP), dikenal dengan adanya pidana penjara minimum umumnya yaitu 1 (satu) hari dan pidana penjara maksimum paling lama 15 (lima belas) tahun sampai 20 (dua puluh) tahun dalam hal pemberatan. Hal ini berlaku dalam tindak pidana narkotika. Pidana minimum khusus adalah ancaman pidana dengan adanya pembatasan terhadap masa hukuman minimum dengan waktu tertentu dimana pidana minimum khusus ini hanya ada pada undang- undang tertentu saja diluar KUHP. Tidak semua Undang-undang mempunyai ancaman pidana minimum khusus. Salah satu Undang-undang yang mempunyai ancaman minimum khusus adalah UndangUndang No. 35 Tahun 2009 tentang Narkotika.

Pidana minimum khusus adalah ancaman pidana dengan adanya pembatasan terhadap masa hukuman minimum dengan waktu tertentu dimana pidana minimum khusus ini hanya ada pada Undang-undang tertentu saja diluar KUHP dan dalam konsep rancangan KUHP yang akan datang. Dengan kata lain tidak semua Undang-undang mempunyai ancaman pidana minimum khusus, salah satu Undang-undang yang mempunyai ancaman minimum khusus adalah Undang-Undang No. 35 Tahun 2009 tentang Narkotika.

Oleh karena itu, dalam penanganan kasus pidana narkotika pada tingkat peradilan, pertimbangan hakim dalam perkara narkotika haruslah mempertimbangkan nilai keadilan masyarakat, tidak hanya mempertimbangkan kepastian hukum saja. Hakim mempunyai tugas untuk menerima, memeriksa, dan mengadili serta memutus perkara, artinya menyelesaikan sengketa pidana. Hakim adalah manusia biasa dengan segala kelemahan dan kekurangan ditempatkan pada posisi sentral dalam menegakkan hukum dan keadilan. ${ }^{2}$

Sudikno Martokusumo menyatakan bahwa: "hakim dalam memutus suatu perkara secara kasuisitas, selalu dihadapkan kepada 3 (tiga) asas, yaitu asas kepastian hukum, asas keadilan, dan asas kemanfaatan. Ketiga asas tersebut (asas kepastian hukum, asas keadilan, asas kemanfaatan) harus dilaksanakan secara kompromi, yaitu menerapkan ketiga-tiganya secara berimbang atau proporsional". ${ }^{3}$

Menurut Undang-Undang No. 35 Tahun 2009 tentang Narkotika, mengatur beberapa putusan yang menjatukan pidana di bawah ancaman pidana minimum khusus, contohnya terdapat dalam Pasal 114 ayat (1) "Setiap orang yang tanpa hak atau melawan hukum menanam, memelihara, memiliki, menyimpan, menguasai, atau menyediakan Narkotika golongan I dalam bentuk tanaman, dipidana dengan penjara paling singkat 4

${ }^{1}$ Fransiska Novita Eleanora, Bahaya Penyalahgunaan Narkoba Serta Usaha Pencegahan Dan Penanggulangannya (Suatu Tinjauan Teoritis), Jurnal Hukum, Vol XXV, No. 1, April 2011, hlm. 439-440

${ }^{2}$ Sidik Sunaryo, Kapita Selekta Sistem Peradilan Pidana, (Malang: Universitas Muhammadiyah Malang, 2004), hlm.27

${ }^{3}$ Sudikno Mertokusumo dan A. Pitlo, Bab-Bab Tentang Penemuan Hukum, (Jakarta: Citra Aditya Bakti, 1993), hlm.10. 
(empat) tahun dan paling lama 12 (dua belas) tahun dan pidana denda paling sedikit Rp. 800.000.000,00 (delapan ratus juta rupiah) dan paling banyak Rp. 8.000.000.000,00 (delapan miliar rupiah). Dalam Pasal tersebut terdapat pertentangan apa yang seharusnya dipertimbangkan oleh hakim dalam mengambil keputusan dalam hal penerapan pidana dengan ancaman pidana minimum tersebut.

Merujuk pada regulasi diatas, seharusnya hakim dalam memutuskan perkara narkotika seyogyanya memberikan hukuman sebagaimana ketentuan yang berlaku. Namun, realitanya hakim cenderung menetapkan sanksi di bawah minimum sehingga bertentangan dengan prinsip legalitas seperti disebutkan dalam peraturan perundangundangan.

Berdasarkan uraian di atas, maka dapat ditentukan beberapa permasalahan dalam tulisan ini yaitu: 1) Bagaimanakah pengaturan sanksi tindak pidana narkotika dikaitkan dengan sanksi di bawah sanksi minimum? Dan, 2) bagaimanakah konsekuensi hukum terhadap putusan hakim yang memutuskan perkara pidana narkotika dengan sanksi di bawah minimum?

\section{Metode Penelitian}

Adapun metode penelitian yang dilakukan dalam membahas permasalahan di atas, menggunakan metode yuridis normatif, yaitu pendekatan yang dilakukan dengan studi kepustakaan dan menetapkan data sekunder sebagai analisys sword. Setelah data diperoleh maka akan disusun secara kualitatif. ${ }^{4}$

\section{Kajian Teoritis Terkait Kewenangan Hakim Dalam Menjatuhkan Sanksi Pidana}

\section{A. Teori Pemidanaan}

Berbicara tentang pidana dan pemidanaan dalam tataran peraturan perundangundangan di Indonesia merupakan suatu hal yang selalu menggejala baik di kalangan ilmuan maupun praktisi hukum terlebih di masyarakat, karena ini merupakan persoalan yang selalu menjadi perbincangan dan selalu mungkin terjadi.

Pidana dimaksudkan sebagai pembalasan atau pengimbalan terhadap kesalahan si pembuat, sedangkan tindakan dimaksudkan untuk perlindungan masyarakat terhadap orang yang melakukan perbuatan yang membahayakan masyarakat dan untuk pembinaan dan perawatan si pembuat. maka terjadi perkembangan sanksi dalam bidang hukum pidana berupa tindakan. ${ }^{5}$ Hal ini menunjukkan, bahwa sanksi dalam hukum pidana semakin dihumanisasikan Selanjutnya dalam proses pemberian pidana atau proses pemidanaan peranan hakim penting sekali. Ia mengkonkritkan sanksi pidana yang

4 Amiruddin, Pengantar Metode Penelitian Hukum, (Jakarta: PT RajaGrafindo Persada, 2012), hlm. 32

5 Siti Nurjanah, Pidana Dan Pemidanaan Dalam Perundang-Undangan Di Indonesia, Jurnal Penelitian Hukum, http:/www.e-jurnal.com/2016/03/pidana-dan-pemidanaan-dalamperundang.html, diakses pada tanggal 3 Februari 2017 
terdapat dalam suatu peraturan dengan penjatuhan pidana untuk orang tertentu dalam kasus tertentu. ${ }^{6}$

Sesuai dengan apa yang dikatakan oleh Barda Nawawi Arief bahwa: "tujuan dari kebijakan pemidanaan yaitu menetapkan suatu pidana tidak terlepas dari tujuan politik kriminal. Dalam arti keseluruhannya yaitu perlindungan masyarakat untuk mencapai kesejahteraan. Oleh karena itu untuk menjawab dan mengetahui tujuan serta fungsi pemidanaan, maka tidak terlepas dari teori-teori tentang pemidanaan yang ada".

Sebagaimana telah terurai, pemidanaan secara sederhana dapat diartikan dengan penghukuman. Penghukuman yang dimaksud berkaitan dengan penjatuhan pidana dan alasan-alasan pembenar (justification) dijatuhkannya pidana terhadap seseorang yang dengan putusan pengadilan yang telah berkekuatan hukum tetap (incracht van gewijsde) dinyatakan secara sah dan meyakinkan terbukti melakukan tindak pidana. ${ }^{8}$

Patut diketahui, bahwa tidaklah semua filsuf ataupun pakar hukum pidana sepakat bahwa negaralah yang mempunyai hak untuk melakukan pemidanaan (subjectief strafrech). Hal ini dapat terlihat jelas pada pendapat Hezewinkel-Suringa sebagaimana dikutip Wirjono Prodjodikoro, yang mengingkari sama sekali hak mempidana ini dengan mengutarakan keyakinan mereka bahwa si penjahat tidaklah boleh dilawan dan bahwa musuh tidaklah boleh dibenci. ${ }^{9}$ Mengenai teori pemidanaan, pada umumnya dapat dikelompokkan dalam tiga golongan besar, yaitu teori absolut atau teori pembalasan (vergeldings theorien), teori relatif atau teori tujuan (doel theorien), dan teori menggabungkan (verenigings theorien). ${ }^{10}$

Menurut teori absolut menyebutkan bahwa ada beberapa macam dasar atau alasan pertimbangan tentang adanya keharusan untuk diadakannya pembalasan itu, yaitu:

- Dari sudut Ketuhanan

Pandangan ini dianut oleh Thomas van Aquino, Stahl, dan Rambonet. Menurut pandangan ini, hukum adalah suatu aturan yang bersumber pada aturan Tuhan yang diturunkan melalui pemerintah negara sebagai wakil Tuhan di dunia. Oleh karenanya, negara wajib memelihara dan melaksanakan hukum dengan cara membalas dengan setimpal bagi setiap pelanggar hukum.

- Dari sudut Ethika

Pandangan ini berasal dari Immanuel Kant, yang dikenal dengan teori "de ethische vergeldings theorie". Berdasarkan pandangan ini, menurut ratio, tiap kejahatan itu harus diikuti oleh suatu pidana. Menjatuhkan pidana adalah suatu yang dituntut oleh keadilan ethis, yang merupakan syarat ethika. Negara mempunyai hak untuk menjatuhkan dan menjalankan pidana dalam rangka memenuhi tuntutan ethika tersebut.

\footnotetext{
${ }^{6}$ Muladi dan Barda Nawawi Arief, Teori-teori dan Kebijakan Pidana, (Bandung: Alumni, 1984), hlm. 2

${ }^{7}$ Ibid., hlm. 4

${ }^{8}$ ibid

9 Wirjono Prodjodikoro, Asas-Asas Hukum Pidana di Indonesia, (Bandung: PT. Refika Aditama, 2008), hlm. 23.

${ }^{10}$ E. Utrecht, Hukum Pidana I, (Jakarta: Universitas Jakarta, 1958), hlm. 157.
} 
- Dari sudut Alam Pikiran Dialektika

Pandangan ini berasal dari Hegel. Menurutnya, pidana mutlak harus ada sebagai reaksi dari setiap kejahatan. Hukum dan keadilan merupakan suatu kenyataan (these). Jika seseorang melakukan kejahatan, berarti ia mengingkari kenyataan adanya hukum (anti these). Oleh karena itulah harus diikuti dengan suatu pidana berupa ketidakadilan terhadap pelakunya (synthese) untuk mengembalikan menjadi suatu keadilan atau kembali tegaknya hukum (these).

- Dari sudut Aesthetica

Pandangan ini berasal dari Herbart, yang dikenal dengan teori "de aesthetica theorie". Menurut teori ini, apabila kejahatan tidak dibalas maka akan menimbulkan rasa ketidakpuasan pada masyarakat. Agar kepuasan dapat dicapai, maka dari sudut aesthetica harus dibalas dengan penjatuhan pidana yang setimpal.

Sementara itu menurut teori relatif menekankan tentang pencegahan terjadinya tindak pidana. Pencegahan yang dimaksud dalam teori ini terdiri dari dua yaitu pencegahan umum (Preventie General) dan pencegahan khusus (Preventie Special). ${ }^{11}$ teori pencegahan umum yang menitikberatkan sifat menakut-nakuti pada penjatuhan pidana secara konkrit oleh hakim pada pelaku, yang dipelopori oleh Muller. Dengan tujuan memberi rasa takut kepada pelaku, maka hakim diperbolehkan menjatuhkan pidana yang beratnya melebihi dari beratnya ancaman pidananya. Maksudnya agar para pelaku lain menjadi terkejut kemudian menjadi sadar bahwa perbuatannya dapat dijatuhi pidana yang lebih berat.

Sementara itu teori pencegahan khusus lebih melihat pada tujuan mencegah niat buruk pelaku (dader) melakukan pengulangan perbuatannya atau mencegah pelanggar melaksanakan perbuatan jahat yang direncanakannya. Tujuan ini dapat dicapai dengan jalan menjatuhkan pidana, yang sifatnya ada tiga macam, yaitu:

- Menakut-nakutinya;

- Memperbaikinya, dan

- Membuatnya menjadi tidak berdaya ${ }^{12}$

Tujuan satu-satunya dari pidana adalah mempertahankan tata tertib hukum di dalam masyarakat. Sebagaimana tujuan teori relative dalam menjaga ketertiban masyarakat, maka pelaku pidana yang dijatuhkan hukuman pidana merupakan salah satu upaya pencegahan.

Kemudian, teori ketiga yaitu teori gabungan yang berorientasikan kepada kombinasi dari teori absolut dan teori relatif yang menggabungkan sudut pembalasan dan pertahanan tertib hukum masyarakat. Menurut, Wirjono Prodjodikoro menyatakan bahwa bagi pembentuk Undang-undang hukum pidana, bagi para jaksa dan hakim dapat memilih salah satu dari ketiga macam teori hukum pidana tersebut dalam menunaikan tugas. ${ }^{13} \mathrm{Hal}$ ini secara tegas disampaikan Wirjono Prodjodikoro dikarenakan nilai-nilai keadilan bukanlah didasarkan dari teori apa yang dianut melainkan berdasarkan unsur humanis

${ }^{11}$ Andi Hamzah, Sistem Pidana dan Pemidanaan Indonesia dari retribusi ke reformasi,(Jakarta: Pradnya Paramita,1985), hlm. 3

${ }^{12}$ Ibid., hlm. 4

${ }^{13}$ Wirjono Prodjodikoro, Op.cit., hlm. 29. 
yang berkenaan dengan kondisi masyarakat dan si pembuat (penjahat) yang diproses melalui perpaduan logika dan hati yang terlahir dalam sebuah nurani.

Merujuk pendapat di atas,maka tujuan dari pemidanaan menurut teori gabungan yaitu:

-Pembalasan, membuat pelaku menderita;

-Upaya prevensi, mencegah terjadinya tindak pidana;

-Merehabilitasi Pelaku;

-Melindungi Masyarakat ${ }^{14}$

Tujuan tersebut juga disebutkan oleh Andi Hamzah yang menyebutkan bahwa teori gabungan memandang pembalasan dan pertahanan tata tertib masyarakat. Namun secara keseluruhan teori gabungan kurang dibahas oleh para sarjana. ${ }^{15}$ Pada saat dikenal kejahatan yang disebut criminal extra ordinaria yang berarti "kejahatan-kejahatan yang tidak disebut dalam undang-undang". Diantara criminal extra ordinaria ini yang terkenal adalah crimina stellionatus (perbuatan durjana/jahat). Dalam hal ini maka dibutuhkan suatu asas hukum yang disebut asas legalitas. ${ }^{16}$

Berdasarkan pandangan legalitas di atas dapat ditekankan bahwa hakim dalam menerapkan hukuman bagi pelaku tindak pidana semestinya juga melihat kembali pada asas legalitas terkait aturan hukum suatu tindak pidana. Sehingga hakim dalam membacakan putusannya juga bersumber pada peraturan perundang-undangan yang berlaku.

\section{B. Konsep Pertimbangan Hakim}

Pertimbangan hakim merupakan salah satu aspek terpenting dalam menentukan terwujudnya nilai dari suatu putusan hakim yang mengandung keadilan (ex aequo et bono) dan mengandung kepastian hukum, di samping itu juga mengandung manfaat bagi para pihak yang bersangkutan sehingga pertimbangan hakim ini harus disikapi dengan teliti, baik, dan cermat. Apabila pertimbangan hakim tidak teliti, baik, dan cermat, maka putusan hakim yang berasal dari pertimbangan hakim tersebut akan dibatalkan oleh Pengadilan Tinggi/Mahkamah Agung. ${ }^{17}$

Hakim dalam pemeriksaan suatu perkara juga memerlukan adanya pembuktian, dimana hasil dari pembuktian itu kan digunakan sebagai bahan pertimbangan dalam memutus perkara. Pembuktian merupakan tahap yang paling penting dalam pemeriksaan di persidangan. Pembuktian bertujuan untuk memperoleh kepastian bahwa suatu peristiwa/fakta yang diajukan itu benar-benar terjadi, guna mendapatkan putusan hakim yang benar dan adil.

${ }^{14}$ Ibid

${ }^{15}$ Andi Hamzah, Op., Cit., hlm. 37

16 Loebby Loqman, Perkembangan Asas Legalitas Dalam Hukum Pidana Indonesia, Bahan Bacaan, Makalah Disampaikan Pada Seminar Tentang Asas-Asas Hukum Pidana Nasional Diselenggarakan Oleh : Badan Pembinaan Hukum Nasional Departemen Kehakiman Dan Hak Asasi Manusia RI Bekerjasama Dengan Fakultas Hukum Universitas Diponegoro Semarang, 2004, hlm. 2-3

${ }^{17}$ Mukti Arto, Praktek Perkara Perdata pada Pengadilan Agama, cet V, (Yogyakarta: Pustaka Pelajar, 2004), hlm.140 
Pada prinsipnya, tugas Hakim adalah menjatuhkan putusan yang mempunyai akibat hukum bagi pihak lain. Namun, Hakim tidak dapat menolak menjatuhkan putusan apabila perkaranya sudah dimulai atau diperiksa. ${ }^{18}$ Kebebasan dalam menetapkan pertimbangan bagi hakim adalah mutlak dan tidak ada suatu pihak manapun yang dapat mengintervensi dalam menjatuhkan putusan. Hal ini bertujuan untuk menjamin agar putusan pengadilan benar-benar obyektif. Selain itu putusan pengadilan oleh Hakim harus dapat dipertanggungjawabkan terhadap Tuhan Yang Maha Esa. ${ }^{19}$

Dasar hakim dalam menjatuhkan putusan pengadilan perlu didasarkan kepada teori dan hasil penelitian yang saling berkaitan sehingga didapatkan hasil penelitian yang maksimal dan seimbang dalam tataran teori dan praktek. Salah satu usaha untuk mencapai kepastian hukum kehakiman, di mana hakim merupakan aparat penegak hukum melalui putusannya dapat menjadi tolak ukur tercapainya suatu kepastian hukum.

Kebebasan hakim perlu pula dipaparkan posisi hakim yang tidak memihak (impartial jugde) Pasal 5 ayat (1) UU No. 48 Tahun 2009. Istilah tidak memihak di sini haruslah tidak harfiah, karena dalam menjatuhkan putusannya hakim harus memihak yang benar. Dalam hal ini tidak diartikan tidak berat sebelah dalam pertimbangan dan penilaiannya. Lebih tapatnya perumusan UU No. 48 Tahun 2009 Pasal 5 ayat (1): "Pengadilan mengadili menurut hukum dengan tidak membeda-bedakan orang". ${ }^{20}$

Kebebasan hakim dalam memeriksa dan mengadili suatu perkara merupakan mahkota bagi hakim dan harus tetap dikawal dan dihormati oleh semua pihak tanpa kesuali, sehingga tidak ada satupun pihak yang dapat mengintervensi hakim dalam menjalankan tugasnya tersebut. Hakim dalam menjatuhkan putusan, harus mempertimbangkan banyak hal, baik itu yang berkaitan dengan perkara yang sedang diperiksa, tingkat perbuatan dan kesalahan yang dilakukan pelaku, sampai kepentingan pihak korban maupun keluarganya serta mempertimbangkan pula rasa keadilan masyarakat.

Menurut Mackenzie, ada beberapa teori atau pendekatan yang dapat dipergunakan oleh hakim dalam mempertimbangkan penjatuhan putusan dalam suatu perkara, yaitu sebagai berikut: ${ }^{21}$

a. Teori Keseimbangan, yaitu keseimbangan antara syarat-syarat yang ditentukan oleh Undang-undang dan kepentingan pihak-pihak yang tersangkut atau berkaitan dengan perkara.

b. Teori Pendekatan Seni dan Intuisi. Yang dimaksud dengan teori Pendekatan Seni dan Intuisi adalah penjatuhan putusan hakim merupakan diskresi atau kewenangan

18 Sudarto. Hukum Pidana Dan Perkembangan Masyarakat Kajian Terhadap Pembaharuan Hukum Pidana, (Bandung: Sinar Baru, 1986), hlm. 84.

${ }^{19}$ Rara Kristi Aditya Mutiaramadani, "Dasar Pertimbangan Hakim dalam Menjatuhkan Sanksi Pidana Penjara terhadap Anak Sebagai Pelaku Tindak Pidana Pencurian dengan Teori Pemidanaan (Studi di Pengadilan Negeri Mojokerto)", (Malang: Universitas Brawijaya, 2013), hlm. 9.

${ }^{20}$ Andi Hamzah, KUHP dan KUHAP, (Jakarta: Rineka Cipta, 1996), hlm. 94

${ }^{21}$ http://digilib.unila.ac.id/5337/8/BAB\%20II.pdf, diakses tanggal 1 Februari 2017 
dari hakim. Sebagai diskresi, dalam penjatuhan putusan, hakim akan menyesuaikan dengan keadaan dan hukuman yang wajar bagi setiap pelaku tindak pidana.

c. Teori Pendekatan Pengalaman. Pengalaman dari seorang hakim merupakan hal yang dapat membantunya dalam menghadapi perkara yang dihadapinya sehari-hari.

d. Teori Pendekatan Keilmuan. Titik tolak dari ilmu ini adalah pemikiran bahwa proses penjatuhan pidana harus dilakukan secara sistematik dan penuh kehatihatian khususnya dalam kaitannya dengan putusan-putusan terdahulu dalam rangka menjamin konsistensi putusan hakim.

e. Teori Ratio Decidendi. Teori ini didasarkan pada landasan filsafat mendasar yang mempertimbangkan segala aspek yang berkaitan dengan pokok perkara yang disengketakan kemudian mencari peraturan perundang-undangan yang relevan dengan pokok perkara yang disengketakan sebagai dasar hukum dalam penjatuhan putusan serta pertimbangan hakim harus didasarkan pada motivasi yang jelas untuk menegakkan hukum dan memberikan keadilan bagi pihak yang berperkara.

f. Teori Kebijaksanaan. Aspek teori ini menekankan bahwa pemerintah, masyarakat, keluarga, dan orang tua ikut bertanggungjawab membimbing, membina, mendidik, dan melindungi terdakwa, agar kelak dapat menjadi manusia yang berguna bagi keluarga, masyarakat, dan bangsanya.

Berdasarkan pendapat di atas, maka dapat ditentukan bahwa hakim merupakan sebuah jabatan yang mewakili Tuhan untuk menegakkan keadilan berdasarkan asas-asas hukum yang berlaku dan memutuskan perkara dengan prinsip kebijaksanaan dan keilmuan yang dimilikinya.

\section{Pembahasan}

\section{Pengaturan Sanksi Tindak Pidana Narkotika Dikaitkan Dengan Sanksi Di Bawah Sanksi Minimum}

Ada beberapa revisi terhadap Undang- undang Nomor 22 Tahun 1997 tersebut karena masih ditemukan beberapa kelemahan selama pelaksanaan atau penerapannya sehingga Undang- undang tersebut diratifikasi pada tahun 2009 sehingga melahirkan Undang- undang Nomor 39 Tahun 2009 tentang Narkotika, yang mana ada beberapa perbedaan dengan undang- undang sebelumnya.

Perumusan pidana minimal yang berlaku di Indonesia sebenarnya diatur dalam KUHP, pada Pasal 12 ayat (2) KUHP untuk pidana penjara dan pasal 18 ayat (1) untuk pidana kurungan. Keduanya mengatur bahwa pidana minimum adalah 1 (satu) hari dan hal ini berlaku umum (general). Sedangkan untuk pidana minimal khusus, secara langsung tidak diatur dalam KUHP, hanya saja diungkapkan pada pasal 103 KUHP bahwa undang-undang diluar KUHP dapat saja mengatur mengenai hal-hal yang khusus (special rules).

Pidana minimum khusus adalah ancaman pidana dengan adanya pembatasan terhadap masa hukuman minimum dengan waktu tertentu dimana pidana minimum khusus ini hanya ada path undang-undang tertentu saja diluar KUHP dan dalam konseprancangan KUHP yang akan datang. Hukuman minimum khusus ditujukan bagi delik-delik yang meresahkan masyarakat dan juga membahayakan bagi masyarakat Tidak 
semua undang - undang mempunyai hukuman pidana minimum khusus, salah satunya adalah Undang - Undang No. 5 tahun 1997 mengenai tindak pidana Psikotropika. Dalam penerapan hukuman pidana minimum khusus mi diharapkan akan memudahkan hakim untuk memutuskan perkara yang tidak terlalu berat karena sering sekali terjadi perbedaan vonis pada kasus yang sama yang disebabkan adanya hal-hal diluar fakta hukum yang dapat mempengaruhi bakim . Tetapi pada kenyataanya masih banyak kekurangankekurangan yang ada hukuman minimum khusus. ${ }^{22}$

Diantaranya adalah adanya kesenjangan vonis masa hukuman yang berbeda dalam berat tindak pidana yang dilakukan tetapi mendapat hukuman yang sama yaitu sama sama mendapatkan hukuman minimum khusus, seharusnya pada kasus yang lebih ringan dapat mendapatkan hukuman yang lebih ringan. Hal tersebut menjdikan pemberian hukuman menjadi tidak ada keadilan. Selain untuk delik yang membahayakan dan meresahkan masyarakat, pidana minimum khusus ditujukan juga untuk membuat efek jera bagi pelaku tindak pidana. Sayangnya pada kenyataannya masih jauh karena untuk pidana penyalahgunaan psikotropika saja para pelaku tindak pidana masih banyak yang melakukan terlihat dan masih tingginya kapasitas lembaga pemasyarakatan yang sebagian besar dihumi oleh narapidana kasus psikotropika.

Berbeda dengan pidana minimal, KUHP justru mengatur pidana maksimal khusus beserta pedoman pemidanaanya. Contohnya pada tindak pidana tertentu dengan kualifikasi corcursus/residive (Pasal 52 dan Pasal 52(a)), serta pada tindak pidana tertentu dengan kualifikasi percobaan/perbantuan. Sehingga, seharusnya ketentuan dalam pemberian pidana maksimal khusus dapat berlaku sama dengan ketentuan dalam pemberian minimal khusus, artinya yang berlaku pada maksimal khusus juga bisa/harus diatur sama pada minimal khusus.

Pencantuman pidana minimal khusus pada peraturan perundang-undangan diluar KUHP saat ini berlaku pada beberapa Undang-Undang, contohnya UU terorisme, UU narkotika, UU penaggulangan bencana dan lainnya. Penjatuhan pidana minimal khusus pada undang-undang tersebut berlangsung secara bervariasi dan tidak terpola dengan baik. Sekalipun delik pidana maksimal khususnya sama namun pidana minimal khususnya tidak sama pada delik serupa, artinya ratio perbandingan antara pidana maksimal khusus dengan pidana minimal khusus juga bervariasi. Seharusnya, penerapan pidana minimal khusus dilaksanakan secara terpola dan memiliki ratio perimbangan yang sama.

Dalam merumuskan peraturan perundang-undangan, struktur hukum yang harus ada adalah unsur subjek hukum, unsur perbuatan yang dilarang, dan unsur ancaman pidana. Pada berbagai undang-undang diluar KUHP, permasalahan nomenklatur mengenai penjatuhan pidana maksimal maupun pidana minimal juga masih beragam.

Selain itu pula, pada kebijakan perumusan Undang-undang, hendaknya sesuai prinsip nulla poena sine lege srticta, maka perumusan jumlah pidana di Indonesia hanya bisa menggunakan fix model dan catagorization model. Dengan berbagai interpretasi bahasa hukum ditambah dengan ragam pola penetapan pidana minimal khusus pada

${ }^{22}$ Andi Hamzah, KUHP dan KUHAP, Op., Cit., hlm. 101 
beberapa undang-undang diluar KUHP serta tidak samanya ratio perbandingan antara pidana maksimal khusus dengan pidana minimal khusus (pada delik yang sama), maka akan menimbulkan permasalahan khususnya pada bagian pengambilan keputusan oleh hakim. $^{23}$

Dengan demikian, hakim diberikan kebebasan yang tidak terukur untuk menentukan/menjatuhkan pidana minimal khusus pada undang-undang khusus tersebut. Pada titik inilah dibutuhkannya kesamaan persepsi dan pelaksanaan mengenai pidana minimal khusus pada undang-undang tertentu diluar KUHP. Harapannya tentu saja agar keputusan yang diambil oleh seorang hakim dapat benar-benar memenuhi rasa keadilan, kemanfaatan, dan kepastian dari hukum itu sendiri.

Produk hakim dari hasil pemeriksaan perkara di persidangan ada 3 (tiga) macam, yaitu:

1) Putusan

2) Penetapan

3) Akta perdamaian

Putusan ialah pernyataan hakim yang dituangkan dalam bentuk tertulis dan diucapkan oleh hakim dalam sidang terbuka untuk umum, sebagai hasil dari pemeriksaan perkara gugatan (kontentius). Penetapan ialah juga pernyataan hakim yang dituangkan dalam bentuk tertulis dan diucapkan oleh hakim dalam sidang terbuka bentuk umum, sebagai hasil dari pemeriksaan perkara permohonan (voluntair). Akta perdamaian ialah akta yang dibuat oleh hakim yang berisi hasil musyawarah antara para pihak dalam sengketa kebendaan untuk mengakhiri sengketa dan berlaku sebagai putusan. ${ }^{24}$

Penentuan pidana minimum dalam undang-undang hukum pidana khusus, merupakan salah satu upaya untuk mengantisipasi agar tidak terjadinya disparitas pidana (disparity of sentencing), di samping sebagai upaya memperkuat prevensi general dan untuk menunjukkan beratnya tindak pidana yang dilakukan. ${ }^{25}$ Disparitas pidana (disparity of sentencing) adalah penerapan pidana yang berbeda terhadap tindak pidana yang sama (same offence) atau terhadap tindak-tindak pidana yang sifat berbahayanya dapat diperbandingkan (offences of comporable seriousness) tanpa dasar pembenaran yang jelas. ${ }^{26}$

Oheo K. Haris menyebutkan dalam tulisannya bahwa:

"Peranan hakim dalam penerapan sanksi minimum da-lam tindak pidana khusus pada proses peradilan pidana sangat besar, yaitu sebagai pem-beri putusan akhir, hakim berpedoman pada peraturan perundang-undangan. Dengan demikian, maka penulis berpendapat bahwa hakim tidak boleh menjatuhkan sanksi di bawah standar minimum. Dengan alasan bahwa negara Indonesia menganut Sistem Kontinental yakni hakim (sebagai pedoman pemidanaan) terikat oleh undangundang (aliran

${ }^{23}$ Ibid.

$24 \mathrm{https}$ //lawindonesia.wordpress.com/hukum-islam/putusan-hakim/, diakses pada tanggal 23 Agustus 2018

${ }^{25}$ Barda Nawawi Arief, Bunga Rampai Hukum Pidana, (Bandung: Citra Aditya Bhakti, 2002), hlm. 124.

${ }^{26}$ Muladi, Kapita Selekta Sistem Peradilan Pidana. (Semarang: Universitas Diponegoro 1995, hlm. 33 
konservatif). Hal tersebut, sebagai realisasi asas the binding persuasive of precedent. Selain itu, konteks sanksi minimum yang terdapat dalam rumusan pasal terhadap tindak pidana khusus, secara terang dan jelas, terdapat pernyataan sanksi pidana yang memuat ketentuan maksimal dan minimal, sehingga tidak memerlukan penafsiran lanjutan". ${ }^{27}$

Majelis hakim yang mempunyai integritas moral yang tinggi dalam mempertahankan kemandiriannya, akan dapat berfungsi sebagai penegak hukum yang baik dalam menjalankan tugas dan wewenang yudisialnya. ${ }^{28}$ Sehingga selama penyelenggaraan proses peradilan, mulai dari pemeriksaan peristiwanya, pembuktian sampai pada putusan yang dijatuhkan, majelis hakim selalu berpedoman pada prinsipprinsip yang dan dapat dipertanggunjawabkan. Putusan hakim pun akan mempunyai tingkat kualitas yang memadai. Para pihak yang berperkara selaku pencari keadilan juga cenderung akan menerima putusan yang telah dijatuhkan, bahkan dengan sukarela akan melaksanakan putusan tersebut, karena dianggap sudah sesuai dengan persaan keadilan masyarakat. $^{29}$

Dalam hal penjatuhan pidana dengan Pasal yang tidak didakwakan, contoh Pasal 127 Undang-Undang No. 35 Tahun 2009 tentang Narkotika, Hakim memeriksa dan memutus perkara harus didasarkan kepada Surat Dakwaan Jaksa Penuntut Umum (Pasal 182 ayat 3 , dan 4 KUHAP), namun apabila berdasarkan fakta hukum yang terungkap di persidangan Terdakwa terbukti sebagai pemakai dan jumlahnya relatif kecil, maka Hakim memutus sesuai surat dakwaan tetapi dapat menyimpangi ketentuan pidana minimum khusus dengan membuat pertimbangan yang cukup. Apabila berdasarkan fakta hukum yang terungkap di persidangan, terdakwa terbukti sebagai pemakai dan jumlahnya relatif kecil, maka hakim memutus sesuai surat dakwaan tetapi dapat menyimpangi ketentuan pidana minimum khusus dengan membuat pertimbangan yang cukup ${ }^{30}$

Berbagai putusan hakim yang senantiasa memutuskan dibawah minimum yang mengakibatkan putusan tersebut telah terjadi inkonsisten sebagaimana yang telah diatur dalam undang-undang. Penjatuhan sanksi terhadap putusan yang ideal dapat memberikan rasa kepastian hukum dan rasa keadilan dalam masyarakat, meskipun sudah ada sebuah teori yang membenarkan disamping itu pula bahwa hakim dapat dikatakan sebagai corong undang-undang. Tanpa adanya konsistensi dalam memu-tuskan perkara pidana khusus yang jelas maka, aturan yang telah ditetapkan dalam undang-undang tersebut akan menemukan rasa ketidakadilan dan ketidakpastian hukum dalam masyarakat, bahkan

${ }^{27}$ Oheo K. Haris, Telaah Yuridis Penerapan Sanksi Di Bawah Minimum Khusus Pada Perkara Pidana Khusus, Jurnal Ius Constituendum Volume 2 Nomor 2 Tahun 2017, hlm. 240

28 Achmad Ali dan Wiwie Heryani, Sosiologi Hukum, Kajian Empiris Terhadap Pengadilan, (Jakarta: Prenada Media Group, 2012, hlm. 12

${ }^{29}$ Bambang Sutiyoso, Sri Hastuti Puspitasari, Aspek-aspek Perkembangan Kekuasaan Keha-kiman Di Indonesia, dikutip dari Sahlan Said,S.H,Kemandirian Kekuasaan Kehakiman- Pengalaman Praktek Menuju Kemandirian Hakim Tolok Ukur dan Kendalanya, Seminar 50 Tahun Kemandirian Kekuasaan Kehakiman di Indonesia di Universitas Gadjah Mada Tanggal 26 Agustus 1995, UII Press, Yogyakarta, 2005, hlm. 87

${ }^{30} \mathrm{https}$ //news.detik.com/berita/3096560/ma-sepakati-vonis-uu-narkotika-boleh-di-bawahancaman-minimal, diakses pada tanggal 23 Agustus 2018 
seolah-olah ada teori baru yang membenarkan bahwa hakim dapat menciptakan teori baru. Padahal dalam bukunya Sudikno Mertokusumo, bahwa seorang hakim harus menggali hukum kepermukaan, bukanlah menciptakan hukum baru.

\section{Konsekuensi Hukum Terhadap Putusan Hakim Yang Memutuskan Perkara Pidana Narkotika Dengan Sanksi Di Bawah Minimum}

Lembaga peradilan di Indonesia dari tahun ke tahun mulai menunjukkan perkembangan yang cukup signifikan. Sebagai salah satu dari lembaga peradilan, hakim saat ini juga mendapat sorotan yang relatif tinggi dari masyarakat dan media. Secara yuridis, hakim merupakan bagian integral dari sistem supremasi hukum. hakim adalah organ pengadilan yang dianggap memahami hukum, yang dipundaknya telah diletakkan kewajiban dan tanggung jawab agar hukum dan keadilan itu ditegakkan, baik yang berdasarkan kepada tertulis atau tidak tertulis (mengadili suatu perkara yang diajukan dengan dalih bahwa hukum tidak atau kurang jelas), dan tidak boleh ada satupun yang bertentangan dengan asas dan sendi peradilan berdasar Tuhan yang Maha Esa. ${ }^{31}$

Pengambilan keputusan sangat diperlukan oleh hakim atas sengketa yang diperiksa dan diadilinya. Hakim harus dapat mengolah dan memproses data-data yang diperoleh selama proses persidangan, baik dari bukti surat, saksi, persangkaan, pengakuan maupun sumpah yang terungkap dalam persidangan (Lihat Pasal 164 HIR). Sehingga keputusan yang akan dijatuhkan dapat didasari oleh rasa tanggung jawab, keadilan, kebijaksanaan, profesionalisme dan bersifat obyektif. ${ }^{32}$ Putusan adalah produk dari pemeriksaan perkara yang dilakukan oleh hakim. Berdasarkan Pasal 178 HIR/189 RBG, setelah pemeriksaan selesai, maka hakim karena jabatannya harus melakukan musyawarah untuk mengambil putusan yang akan dijatuhkan.

Putusan yang dijatuhkan oleh hakim harus bedasarkan pertimbangan yang jelas dan cukup. Putusan yang tidak memenuhi ketentuan tersebut dikategorikan putusan yang tidak cukup pertimbangan atau onvoldoende gemotiveerd. Alasan yang dijadkan pertimbangan dapat berupa pasal-pasal tertentu peraturan perundang-undangan, hukum kebiasaan, yurisprudensi atau doktrin hukum. ${ }^{33}$

Sebagaimana diketahui bahwa dalam perkara pidana, berlaku asas pembuktian; beyond reasonable doubt, yang artinya, dalam menjatuhkan putusannya, hakim bukan hanya terikat dengan alat-alat bukti yang sah, melainkan juga masih harus ditambah adanya keyakinan hakim. Inilah yang kemudian menjadi alasan oleh hakim menjatuhkan putusan yang menurutnya sesuai dengan nalar dan hati nuraninya. Jika memang menurut

${ }^{31}$ Bambang Waluyo, S.H. Implementasi Kekuasaan Kehakiman Republik Indonesia, Edisi 1 Cet. 1., (Jakarta: Sinar Grafika, 1991). hlml 11

${ }^{32}$ Oheo K. Haris, Loc., Cit.

${ }^{33}$ M. Yahya Harahap, Hukum Acara Perdata, (Jakarta: Sinar Grafika, 2005), hlm. 798 
keyakinan hakim putusan yang diberikan itu memberikan rasa keadilan maka hal tersebut dapat saja dilakukan. ${ }^{34}$

Senada dengan hal tersebut, Satjipto Rahrjo menggambarkan bahwa tidaklah haram bagi hakim untuk menyimpangi undang-undang jika keadilan dapat diperoleh dengan menyimpangi undang-undang tersebut dan justru ketidakadilan akan muncul jika ketentuan dalam aturan perundang-undangan tersebut diterapkan. ${ }^{35}$

Penentuan berat ringannya pidana merupakan diskresi yang dimiliki oleh hakim. Beberapa faktor yang harus diperhatikan terkait dengan penentuan nilai pidana: Faktor dampak kejahatan; Faktor modus operandi kejahatan; Faktor perilaku terdakwa di persidangan; Faktor perdamaian antara terdakwa dan korban; Faktor pribadi hakim yang memutus. $^{36}$

Hakim dapat memutus dibawah ancaman minimum undang-undang, dalam hal terbukti di persidangan bahwa terdakwa adalah pengguna (Pasal 127 UU Narkotika) tapi pasal tersebut tidak didakwakan Jaksa Penuntut Umum kepadanya. Dasar hukumnya, Surat Edaran Mahkamah Agung No. 3 tahun 2015 tentang Pemberlakukan Rumusan Hasil Rapat Pleno Kamar Mahkamah Agung Tahun 2015 Sebagai Pedoman Pelaksanaan Tugas Bagi Pengadilan, yaitu pada bagian A angka 1 yang berbunyi:

"Hakim memutus dan memeriksa perkara harus didasarkan kepada Surat Dakwaan Jaksa Penuntut Umum (Pasal 128 ayat 3, dan 4 KUHAP). Jaksa mendakwa dengan Pasal 111 atau Pasal 112 Undang-Undang No. 35 tahun 2009 tentang Narkotika (UU Narkotika) namun berdasarkan fakta hukum yang terungkap di persidangan terbukti Pasal 127 UU Narkotika yang mana pasal ini tidak didakwakan, Terdakwa terbukti sebagai pemakai dan jumlahnya relatif kecil (SEMA 4 Tahun 2010), maka hakim memutus sesuai surat dakwaan tetapi dapat menyimpangi ketentuan pidana minimum khusus dengan membuat pertimbangan yang cukup., ${ }^{, 7}$

Umumnya dalam perkara narkotika dimana hakim memutus perkara dengan sanksi pidana minimum ditemukan bahwa di dalam pertimbagan hakim dalam putusan perkara narkotika pada intinya adalah karena Pentuntut Umum hanya mendakwa Terdakwa dengan Pasal 112 UU Narkotika namun tidak mendakwa dengan Pasal 127 UU Narkotika padahal di persidangan terbukti Terdakwa ini adalah pengguna narkotika sehingga seharusnya didakwa dengan Pasal 127 UU Narkotika.

Berdasarkan ketentuan di atas, maka bisa dipahami bahwa dalam perkara Narkotika, hakim dapat memutus menyimpangi ketentuan pidana minimum undangundang jika terbukti di persidangan bahwa Terdakwa merupakan pengguna (Pasal 127

\footnotetext{
${ }^{34}$ Achmad Ali, Menguak Teori Hukum (Legal Theory) \& Teori Peradilan (Judicial Prudence): Termasuk Interpretasi Undang-Undang (Legisprudence), (Jakarta: Kencana Prenadamedia Group, 2009), hlm. 481.

${ }^{35}$ Darmoko Yuti Witanto, Diskresi Hakim: Sebuah Instrumen Menegakkan Keadilan Substantif dalam Perkara-perkara Pidana, (Bandung: ALFABETA, 2013), hlm. 123.

${ }^{36}$ Ibid.

${ }^{37}$ https://konsultanhukum.web.id/dasar-hukum-hakim-memutus-di-bawah-ancaman-pidanaminimum-dalam-perkara-narkotika/, diakses pada tanggal 26 Agustus 2018
} 
UU Narkotika), namun pasal tersebut tidak didakwakan oleh Jaksa Penuntut Umum kepada Terdakwa.

\section{Penutup}

Berdasarkan hasil dan pembahasan maka dapat disimpulkan bahwa adanya penjatuhan pidana di bawah minimum jelas bertentangan dengan asas legalitas jika mendasarkan pada penafsiran peraturan perundang-undangan yang telah ada yang melahirkan penemuan hukum oleh hakim, yang menyebabkan tidak adanya kepastian hukum. Sebab menurut Asas Legalitas sebagaimana yang dimaksud di dalam Pasal 1 ayat (1) KUHP yaitu nullapoena sine lege memberikan makna bahwa setiap sanksi pidana haruslah ada peraturan hukum yang mengatur sebelumnya, sedangkan penafsiran hukum yang melahirkan penemuan hukum oleh hakim tersebut tidaklah diperlukan bilamana telah ada aturan yang secara jelas dan tegas diatur dalam peraturan perundangundangan, agar mewujudkan tujuan hukum yakni rasa keadilan, kepastian hukum dan kemanfaatan.

menyarankan agar peraturan perundang-undangan tersebut harus jelas dan tegas demi terwujudnya tujuan hukum yakni keadilan, kepastian dan kemanfaatan sehingga hakim tidak melakukan penafsiran/penemuan hukum yang akan menimbulkan disparitas dalam penjatuhan pidana.

\section{Daftar Pustaka}

\section{Buku:}

Achmad Ali dan Wiwie Heryani, Sosiologi Hukum, Kajian Empiris Terhadap Pengadilan, (Jakarta: Prenada Media Group, 2012

Achmad Ali, Menguak Teori Hukum (Legal Theory) \& Teori Peradilan (Judicial Prudence): Termasuk Interpretasi Undang-Undang (Legisprudence), Kencana Prenadamedia Group, Jakarta, 2009

Amiruddin, Pengantar Metode Penelitian Hukum, PT RajaGrafindo Persada. Jakarta, 2012

Andi Hamzah, KUHP dan KUHAP, Rineka Cipta, Jakarta, 1996

Andi Hamzah, Sistem Pidana dan Pemidanaan Indonesia dari retribusi ke reformasi,Pradnya Paramita, Jakarta, 1985

Bambang Sutiyoso, Sri Hastuti Puspitasari, Aspek-aspek Perkembangan Kekuasaan Keha-kiman Di Indonesia, dikutip dari Sahlan Said,S.H,Kemandirian Kekuasaan Kehakiman- Pengalaman Praktek Menuju Kemandirian Hakim Tolok Ukur dan Kendalanya, Seminar 50 Tahun Kemandirian Kekuasaan Kehakiman di Indonesia di Universitas Gadjah Mada Tanggal 26 Agustus 1995, UII Press, Yogyakarta, 2005

Bambang Waluyo,. Implementasi Kekuasaan Kehakiman Republik Indonesia, Sinar Grafika Edisi 1 Cet. 1. Jakarta 1991 
Barda Nawawi Arief, Bunga Rampai Hukum Pidana, Citra Aditya Bhaki, Bandung, 2002

Darmoko Yuti Witanto, Diskresi Hakim: Sebuah Instrumen Menegakkan Keadilan Substantif dalam Perkara-perkara Pidana, ALFABETA, Bandung, 2013

Fransiska Novita Eleanora, Bahaya Penyalahgunaan Narkoba Serta Usaha Pencegahan Dan Penanggulangannya (Suatu Tinjauan Teoritis), Jurnal Hukum, Vol XXV, No. 1, April 2011

Loebby Loqman, Perkembangan Asas Legalitas Dalam Hukum Pidana Indonesia, Bahan Bacaan, Makalah Disampaikan Pada Seminar Tentang Asas-Asas Hukum Pidana Nasional Diselenggarakan Oleh : Badan Pembinaan Hukum Nasional Departemen Kehakiman Dan Hak Asasi Manusia RI Bekerjasama Dengan Fakultas Hukum Universitas Diponegoro Semarang, 2004

M. Yahya Harahap, Hukum Acara Perdata, Sinar Grafika, Jakarta, 2005

Mukti Arto, Praktek Perkara Perdata pada Pengadilan Agama, cet V, Pustaka Pelajar, Yogyakarta, 2004

Muladi dan Barda Nawawi Arief, Teori-teori dan Kebijakan Pidana, Alumni, Bandung, 1984

Muladi, Kapita Selekta Sistem Peradilan Pidana. (Semarang: Universitas Diponegoro 1995

Oheo K. Haris, Telaah Yuridis Penerapan Sanksi Di Bawah Minimum Khusus Pada Perkara Pidana Khusus, Jurnal Ius Constituendum Volume 2 Nomor 2 Tahun 2017

Rara Kristi Aditya Mutiaramadani, "Dasar Pertimbangan Hakim dalam Menjatuhkan Sanksi Pidana Penjara terhadap Anak Sebagai Pelaku Tindak Pidana Pencurian dengan Teori Pemidanaan (Studi di Pengadilan Negeri Mojokerto)", Universitas Brawijaya, Malang, 2013

Sidik Sunaryo, Kapita Selekta Sistem Peradilan Pidana, Universitas Muhammadiyah Malang, Malang, 2004

Sudarto. Hukum Pidana Dan Perkembangan Masyarakat Kajian Terhadap Pembaharuan Hukum Pidana, Sinar Baru, Bandung, 1986

Sudikno Mertokusumo dan A. Pitlo, Bab-Bab Tentang Penemuan Hukum, Citra Aditya Bakti, Jakarta, 1993

Utrecht E., Hukum Pidana I, Universitas Jakarta, Jakarta, 1958

Wirjono Prodjodikoro, Asas-Asas Hukum Pidana di Indonesia, PT. Refika Aditama, Bandung, 2008

\section{Internet:}

http://digilib.unila.ac.id/5337/8/BAB\%20II.pdf, diakses tanggal 1 Februari 2017

http://www.e-jurnal.com/2016/03/pidana-dan-pemidanaan-dalam-perundang.html, diakses pada tanggal 3 Februari 2017 
Volume 13, Nomor 2, Juli-Desember 2018

https://konsultanhukum.web.id/dasar-hukum-hakim-memutus-di-bawah-ancaman-pidanaminimum-dalam-perkara-narkotika/, diakses pada tanggal 26 Agustus 2018

https://lawindonesia.wordpress.com/hukum-islam/putusan-hakim/, diakses pada tanggal 23 Agustus 2018

https://news.detik.com/berita/3096560/ma-sepakati-vonis-uu-narkotika-boleh-di-bawahancaman-minimal, diakses pada tanggal 23 Agustus 2018 